TARNOWSKIE STUDIA TEOLOGICZNE 36 (2017) NR 1, S. 83-97

http://dx.doi.org/10.15633/tst.2325

ks. Tomasz Stec ${ }^{1}$

UNIWERSYTET PAPIESKI JANA PAWŁA II W KRAKOWIE

\title{
Handel organami ludzkimi - problem nadal aktualny
}

Zdrowe organy, tkanki, komórki to składowe ludzkiego organizmu, dzięki którym może on poprawnie funkcjonować. Niestety współczesny tryb życia, przemiany społeczne, uwarunkowania genetyczne, niezdrowa żywność i jeszcze wiele innych czynników negatywnie wpływają na nasze zdrowie. W efekcie tego coraz częściej słyszymy o pojawiających się nowych chorobach cywilizacyjnych. Jeszcze większym problemem dla człowieka są dziś takie zaburzenia, na skutek których przestaje prawidłowo funkcjonować któryś z narządów. Bywa, że jedynym wówczas sposobem leczenia jest przeszczep. Gdy jedni ludzie przeżywają tragedię, walczą o życie, inni wykorzystują ich trudną sytuację do indywidualnego zarobku, np. oferują swój narząd za określoną cenę. W środkach społecznego przekazu można usłyszeć nieraz o przestępczych gangach, skłonnych do porywania małych dzieci lub młodych ludzi w celu pobrania i sprzedania ich organów. Takie działanie kończy się śmiercią niewinnego człowieka oraz tragedią całych rodzin. $\mathrm{Z}$ tego powodu wszelki handel organami i nielegalna chęć ich pozyskiwania są ścigane prawnie. Podobnie od strony moralnej działanie takie określane jest w kategorii najcięższego grzechu. Wina moralna polega tu na niszczeniu ludzkiego życia, które dla każdego człowieka jest dobrem najwyższym².

Handel organami, jak się okazuje, pomimo wszelkich unormowań prawnych, nadal istnieje. Co ciekawe, problem nie dotyczy tylko krajów ubogich. Zmaga się z nim cały świat. Ostatnie informacje docierające z policji wskazują na pojawienie się tego problemu także w naszym państwie.

1 Tomasz Stec - kapłan archidiecezji przemyskiej, ukończył studia magisterskie w Przemyślu w 2010 roku, pracował jako wikariusz w parafii Dubiecko i Strachocina. Od 2014 roku podejmuje studia licencjacko-doktoranckie na Papieskim Uniwersytecie Jana Pawła II w Krakowie. W 2015 roku uzyskał tytuł magistra licencjata z teologii moralnej, specjalizacja - bioetyka.

2 Por. T. Ślipko, Zarys etyki ogólnej, Kraków 2004, s. 227. 


\section{Współczesne problemy transplantologii}

Transplantacja (łac. transplantare - szczepić, przesadzić), czyli przeszczepienie z organizmu dawcy do organizmu biorcy narządów, komórek lub tkanek wymaga odpowiednich unormowań prawnych i moralnych. Żadnej pożądanej części organizmu w przypadku chorego pacjenta nigdy nie można kupić, przekazanie zaś musi nastąpić za wcześniejszą zgodą dawcy ${ }^{3}$.

Od momentu pierwszego przeszczepu nerki, której w 1954 roku dokonał Joseph E. Murray ${ }^{4}$, i od pierwszego przeszczepienia serca w dokonanego w 1967 roku przez zespół medyczny Christiana Barnarda ${ }^{5}$ wiele zmieniło się w transplantologii. Dzisiaj bez większych problemów i powikłań dokonujemy przeszczepów takich organów, jak serce, wątroba, nerka czy trzustka. Przeszczepiane są także tkanki i komórki. Nierzadkie są transplantacje płuc, jelit lub kończyn oraz komórek krwiotwórczych, fragmentów kostnych, czy nawet rogówki oka ${ }^{6}$.

Problemem nadal jest jednak brak organów do przeszczepu. Podwójne narządy zazwyczaj pozyskuje się od osób bliskich. Sytuacja staje się trudniejsza, gdy pojawia się zapotrzebowanie na narządy pojedyncze. Najczęściej pobiera się je wówczas od dawców zmarłych ${ }^{7}$. Niestety, przeszczepione w ten sposób organy bywają częściej odrzucane przez organizm biorcy. Wynika to między innymi z tego, że niedokrwienie organów - nawet przez krótki okres - wpływa na powodzenie przeszczepu ${ }^{8}$. Pewnym rozwiązaniem

3 Ustawa z dnia 1 lipca 2005 r. o pobieraniu, przechowywaniu i przeszczepianiu komórek, tkanek i narządów (ogłoszona 6 września 2005 r., weszła w życie 1 stycznia 2006 r.), „Dziennik Ustaw Rzeczypospolitej Polskiej” [dalej Dz.U.] Nr 169, poz. 1411, art. 5.1; Ustawa z dnia 26 października 1995 r. o pobieraniu i przeszczepianiu komórek, tkanek i narządów (obowiązywała do 1 stycznia 2006 r.), Dz.U. Nr 138, poz. 682, art. 18,19 i 20.

4 Por. J. Skalski, Historia przeszczepiania narządów, „CX-News” 28 (2009) nr 2, s. 244; zob. J. Sobiak, Przeszczepianie narządów i komórek krwiotwórczych - rys historyczny, „Nowiny Lekarskie" 80 (2011) nr 2, s. 157-161.

5 Por. R. Hoffenberg, Christiaan Barnard: His First Transplants and Their Impact on Concepts of Death, „British Medical Journal” 12 (2001), s. 12-22.

6 Por. M. Lanzetta, P. Petruzzo, G. Vitale i in., Human Hand Transplantation: What Have we Learned?, „Transplantation Proceedings” 36 (2004), s. 664-668.

7 Por. „Poltransplant. Biuletyn Informacyjny” 2014 nr 1 (22), s. 20: Centrum Organizacyjno-Koordynacyjne ds. Transplantacji „Poltransplant” podaje, że zdecydowana większość narządów pozyskiwana jest właśnie w ten sposób. W roku 2014 przeszczepiono 1531 organów, podczas gdy w 2013 od zmarłych dawców pochodziło ich 1536, a w 2012 - 1545.

8 Por. „Poltransplant. „Biuletyn Informacyjny” 2014 nr 1 (22), s. 16. 
było wprowadzenie harwardzkich kryteriów śmierci. Możliwość orzekania o śmierci pacjenta na skutek nieodwracalnych zmian, jakie zaszły w mózgu, poszerzyła grono dawców. Niemniej jednak zawsze kontrowersyjna pozostaje tutaj zgoda domniemana na pobranie organów, a rodzące się wciąż głosy o niemoralnym stosowaniu nowych kryteriów śmierci dodatkowo obniżają liczbę dawców. Rośnie więc liczba oczekujących na transplantacje, a dawców jest nadal za mało ${ }^{9}$.

Edukacja społeczna ludzi w tym zakresie zaowocowała powstaniem krajowych rejestrów dawców, które prowadzą spis osób zdecydowanych oddać swoje komórki lub organy potrzebującym. Każdy człowiek może świadomie wyrazić zgodę na pobranie organów po swojej śmierci lub sprzeciwić się temu zabiegowi. Duża liczba świadomych dawców sprawia, że poprzez odpowiedzialną postawę można uratować wielu chorych oczekujących na przeszczep.

W ubiegłym roku w Polsce dane dotyczące transplantacji przedstawiały się następująco. Od dawców zmarłych pobrano łącznie 1434 narządy, głównie nerki, wątrobę, serce i płuca. Od dawców żywych przeszczepiono prawie 100 nerek i fragmentów wątroby. Tymczasem na transplantacje oczekują: na nerkę prawie tysiąc osób, na nowe serce ponad 360, na wątrobę - ponad 170 . Ponad 3 tys. chorych oczekuje na przeszczep rogówki ${ }^{10}$.

Statystyki oczekujących na transplantacje przedstawiają się podobnie w innych krajach Europy i świata. Ciągle rośnie liczba chorych i zapotrzebowanie na narządy oraz nadal brakuje organów, które po przeszczepie dałyby potrzebującym nadzieję na dalsze życie. Ta trudna sytuacja staje się okazją do szybkiego zarobku dla działających wbrew prawu i wszelkim zasadom moralnym przestępczych gangów handlujących narządami.

\section{Czarny rynek organów}

Handel organami ludzkimi, pomimo wielkiego na nie zapotrzebowania, jest zakazany i negatywnie postrzegany przez większość krajów świata. Różne autorytety moralne i etyczne postrzegają takie działanie jako największe zło moralne. Zezwolenie na pobieranie jakiejkolwiek rekompensaty za oddanie tkanki lub narządu skutkuje wzrostem przestępczości w tej dziedzinie.

9 Por. M. Gardocka, Problem zgody domniemanej w polskiej transplantologii, „Warszawskie Studia Teologiczne" 26 (2013) nr 1, s. 247-26o.

${ }_{10}$ Por. http://www.poltransplant.org.pl/statystyka_2015.html (12.01.2016). 
Przekonały się o tym poszczególne kraje, których prawodawca stworzył zapis umożliwiający pozyskanie organów do przeszczepu w inny sposób niż w wyniku darowania ich przez najbliższą rodzinę lub na skutek pobrania od zmarłego dawcy ${ }^{11}$.

Człowieka nie wolno nigdy traktować jako środka do celu, ale jako cel sam w sobie ${ }^{12}$. Wynika to $\mathrm{z}$ posiadanej przez każdego godności. Pomiędzy człowiekiem a rzeczą istnieje ta różnica, że rzeczy mają swoją cenę, osoba ludzka zaś jest poza wszelką ceną. Moralność chrześcijańska stoi na straży tej godności, aby nigdy nie doszło do tego, co proponowali w ubiegłych epokach Karol Marks, Georg W. F. Hegel czy Thomas Hobbes, a mianowicie do zrównania wartości osoby ludzkiej z rzeczami.

Co jakiś czas pojawiają się jednak w prasie i mediach informacje ukazujące dramaty ludzi, którzy na skutek traktowania człowieka jako środka do celu porywają dzieci bądź handlują własnymi organami. Sprawy znikania dzieci spod supermarketów, z dużych placów zabaw, następnie informacje o próbach wywiezienia ich nielegalnym transportem za granicę nie są dzisiaj jednostkowe. Podobnie, co jakiś czas, można usłyszeć o pojawiających się na stronach internetowych ofertach i cenach, za którą ktoś chętnie odsprzeda swoją chorą nerkę ${ }^{13}$.

W prowadzonym podziemnym biznesie wyróżnić można dwie grupy ludzi: tych, którzy kupują, i tych, którzy sprzedają. Handel narządami, tkankami i komórkami wynika zazwyczaj ze złych warunków socjalno-ekonomicznych. Ludzie z biednych państw świata, takich jak Pakistan, Kolumbia, Filipiny, Egipt, czy nawet z Europy: Turcji, Mołdawii i Rumunii, postanawiają poprzez oddanie narządu (najczęściej nerki bądź fragmentu wątroby) poprawić swój byt ${ }^{14}$. Silke Meyer ${ }^{15}$ mówi: „[...] handel organami wiąże się z uzyskaniem

${ }^{11}$ W USA prawo zezwala na pobieranie rekompensaty finansowej za niektóre tkanki czy substancje. Zob. G. Hołub, O dwóch sposobach pozyskiwania organów do transplantacji, „Studia Gdańskie” 25 (2009), s. 129-146.

${ }^{12}$ Kantowska zasada mówi: „Postępuj tak, byś człowieczeństwa tak w twej osobie jako też w osobie każdego innego używał zarazem jako celu, nigdy tylko jako środka” (I. Kant, Uzasadnienie metafizyki moralności, tłum. R. Ingarden, Warszawa 1984, s. 64).

${ }_{13}$ Por. A. Jasińska, Łódzkie: porwania dla narządów. To nie legenda, „Dziennik Łódzki” Z 11 czerwca 2011.

${ }^{14}$ Por. R. Panjabi, The Sum of A Human's Parts: Global Organ Trafficking in the Twenty-First Century, „Pace Environmental Law Review” 28 (2010) no. 1, s. 75.

${ }_{15}$ Pracownik socjalny i kryminolog, profesor nadzwyczajny w Katedrze Historii i Etnologii Europejskiej na Uniwersytecie w Innsbrucku od 2016 roku. 
środków na życie w wypadku ludzi, którzy żyją na bardzo niskim poziomie społeczno-ekonomicznym. Są oni skłonni sprzedać organ - zwykle nerkę, ponieważ jest to organ najczęściej pobierany od żyjących dawców - w celu polepszenia swoich warunków życia"16.

Będąc pod presją ubóstwa, ludzie godzą się poświęcić własne zdrowie, a niekiedy i życie. Sheila M. Rothman, profesor zdrowia publicznego na Uniwersytecie Columbia i badaczka tego problemu na terenie Indii stwierdza, że po sprzedaży organów byt tych ludzi i ich rodzin wcale się nie polepsza. Wręcz przeciwnie, brak odpowiedniej opieki medycznej po zabiegach, brak potrzebnych leków sprawiają, że ludzie ci często po oddaniu narządu umierają $^{17}$. W Indiach państwo zezwala na przekazanie nerki osobie, z którą dawca jest spokrewniony, lub innemu potrzebującemu, z którym dawca jest w jakiejś „relacji”. Zapis ten otwiera drogę do wielu nadużyć w tej dziedzinie. W Madrasie istnieje nawet dzielnica Kidneyvakkam (wioska nerek), w której większość zamieszkujących rodzin sprzedała organ. Nancy Scheper-Hughes ${ }^{18}$, mówi, że mamy tu do czynienia $\mathrm{z}$, «apartheidem medycznym», który uprzywilejowuje jedną klasę pacjentów, odbiorców organów, kosztem innej klasy niewidocznych i trudnych do określenia «nie-pacjentów», o których niewiele wiadomo"19.

Od dłuższego czasu istnieją ludzie, którzy trudnią się wyszukiwaniem i przeprowadzaniem nielegalnych transakcji. Są to tzw. „porywacze organów” (organ snatchers), którzy wyszukują np. młodych zdrowych mężczyzn z biednych krajów, oferują im łatwy zarobek, przy czym sami zabierają większą część pieniędzy. Sumy oferowane za nerkę kilkukrotnie przekraczają cenę, którą zaoferowano dawcy. Jak donoszą organizacje zwalczające czarny handel, dawca otrzymuje tysiąc dolarów, podczas gdy nerka sprzedawana jest za cenę od 5 do 15 tys. dolarów ${ }^{20}$.

${ }^{16}$ S. Meyer, Trafficking in Human Organs in Europe. A Myth or an Actual Threat?, „European Journal of Crime, Criminal Law and Criminal Justice” 14 (2006) no. 1, s. 215.

${ }_{17}$ Zob. S. M. Rothman, D. J. Rothman, The Hidden Cost of Organ Sale, „American Journal of Transplantation" 6 (2006) no. 7, s. 1524-1528.

${ }^{18}$ Jest profesorem antropologii i dyrektorem programu $\mathrm{z}$ antropologii medycznej na Uniwersytecie Kalifornijskim w Berkeley. W 2009 roku jej śledztwo w sprawie międzynarodowego pierścienia sprzedawców organów z siedzibą w Nowym Jorku, New Jersey i Izraelu doprowadziło do licznych aresztowań przez FBI.

${ }^{19}$ N. Scheper-Hughes, Rotten Trade: Millennial Capitalism, Human Values and Global Justice in Organ Trafficking, "Journal of Human Rights” 2 (2003) no. 2, s. 197-226.

${ }^{20}$ Por. G. Hołub, O dwu sposobach pozyskiwania organów do transplantacji..., s. 131-132. 
Problem handlu nasila się dzisiaj szczególnie w Chinach. Wiele organów pozyskuje się od więźniów, na których wykonano karę śmierci. Liczba zgonów jest objęta tajemnicą wojskową, ale badacze problemu twierdzą, że rocznie karze śmierci poddawane jest $\mathrm{w}$ tym kraju ponad 4 tys. osób. Wyroki wykonywane są w tzw. ",autobusach egzekucyjnych”, stojących w pobliżu szpitali. Gwarantuje to szybki transport organów. Jeszcze bardziej ułatwiony jest handel narządami w Iranie. Tu prawo dopuszcza oddanie za pieniądze własnej nerki. Stąd zamiast kolejek oczekujących, przy szpitalach ustawiają się kolejki dawców. Nerka kosztuje tam ok. 15 tys. zł, a dawcy do części tej kwoty dopłaca państwo. Irańczykom nie wolno jednak sprzedawać narządów obcokrajowcom ${ }^{21}$.

W ostatnich latach coraz częściej mówi się również o tzw. turystyce transplantacyjnej. Potrzebujący transplantacji, majętni ludzie, udają się na „wakacje”, podczas których zostaje wymieniony im za odpowiednią cenę (200-40o tys. zl) chory narząd. Takie sytuacje zaobserwowano w bogatych krajach Europy Zachodniej, usA, Japonii, Korei Południowej, RPA. Cena za narząd waha się w zależności od narodowości, z której pochodzi dawca, np. serce w Korei Południowej, w Tajwanie kosztuje 900 tys. zł, w RPA 400 tys., w Kolumbii tylko 280 tysięcy. Ceny innych narządów też są ustalone i znajdują licznych zainteresowanych ${ }^{22}$.

\section{Problem handlu organami w Polsce}

W Polsce sprawę transplantacji reguluje Ustawa z dnia 1 lipca 2005 r. o pobieraniu, przechowywaniu i przeszczepianiu komórek, tkanek i narządów. Artykuł 43 ustawy zabrania pobierania i przyjmowania zapłaty lub innej korzyści majątkowej od biorcy narządu. Prawodawca przywiduje karę dla każdego, kto nabywa lub sprzedaje organy lub komórki, a także dla tego, kto rozpowszechnia informacje na podany temat ${ }^{23}$.

${ }^{21}$ Por. M. Powęska, Nerka za 30 tys. zł, płuca za milion. Jak wygląda handel ludzkimi organami?, http://nt.interia.pl/raporty/raport-medycyna-przyszlosci/medycyna/news-nerka-za30-tys-zl-pluca-za-milion-jak-wyglada-handel-ludzki,nId,1060289 (10.06.2016).

${ }_{22}$ Por. M. Powęska, Nerka za 30 tys. zł, płuca za milion...

${ }_{23}$ Zob. Ustawa z dnia 1 lipca 2005 r. o pobieraniu, przechowywaniu i przeszczepianiu komórek, tkanek i narządów, art. 3, 43, 44; zob. S. Buczyński, P. Snopek, Aspekty kryminologiczne nielegalnego obrotu narządami, tkankami oraz komórkami ludzkimi, „Hygeia Public Health” 49 (2013), s. 229-234. 
Prawodawca stanowi, że każdy „kto rozpowszechnia ogłoszenia o odpłatnym zbyciu, nabyciu lub o pośredniczeniu w odpłatnym zbyciu lub nabyciu komórki, tkanki lub narządu w celu ich przeszczepiania, podlega grzywnie, karze ograniczenia wolności lub karze pozbawienia wolności do roku" (art. 43). Odpowiedzialność karna za sfinalizowanie powyższej transakcji to kara pozbawienia wolności do lat trzech. Podobnie karany będzie ten, kto uczynił sobie źródło stałego dochodu z procederu handlu organami (prawodawca powie tu o karze pozbawienia wolności do lat pięciu). Ponadto, w świetle ustawy transplantacyjnej każdy „Kto bez wymaganego pozwolenia, pobiera komórkę, tkankę lub narząd w celu ich przeszczepienia albo je przeszczepia, podlega grzywnie, karze ograniczenia wolności albo pozbawienia wolności do lat 3” (art. 46). Karze grzywny bądź ograniczenia wolności podlega ten, kto prowadzi działalność przewidzianą przepisami ustawy dla banku komórek i tkanek, bez wymaganego pozwolenia (art. 45) ${ }^{24}$.

To, że powstała taka ustawa, sugeruje, że problem nielegalnego pozyskiwania organów dotyczy także nas samych. Centralne Biuro Śledcze (свś) w 2012 roku przeprowadziło na terenie całej Polski akcję wymierzoną w osoby mogące mieć związek z handlem lub propozycją sprzedaży narządów. Zatrzymano wówczas 23 osoby, którym następnie postawiono zarzuty. W toku całej sprawy przesłuchano łącznie 105 osób, a śledztwa toczą się nadal ${ }^{25}$.

Czynniki, które popychają najczęściej młodych ludzi w Polsce do takich działań, jak oferowanie sprzedaży własnej nerki, są podobne jak w innych krajach świata: brak zatrudnienia, rosnące długi, niemożliwość utrzymania siebie i własnej rodziny, problemy w spłacie kredytów itd. Oferty zazwyczaj zamieszczają ludzie, których przeszłość powiązana jest z jakimś kryminalnym zdarzeniem. Osoby będące w desperacji całą sprawę utrzymują w wielkiej tajemnicy. Gdy trafiają do grupy handlującej organami, często godzą się na o wiele niższą cenę za swój narząd, na rzecz tych, którzy trudnią się procederem handlu. Często są to młodzi mężczyźni. Niestety, sam zabieg zazwyczaj nie kończy się tylko na pobraniu nerki. Wycinane są również inne narządy, a ciało jest gdzieś zakopywane. Gangi handlujące organami są świadome, że o tę osobę nikt nie będzie się dopytywał, bo cały sposób jego działania utrzymany jest zazwyczaj w tajemnicy nawet przed najbliższą rodziną. Niekiedy handlarze przedstawiają sprawę jeszcze

${ }^{24}$ Por. S. Buczyński, P. Snopek, Aspekty kryminologiczne..., s. 229-234.
${ }_{25}$ Por. http://www.policja.pl/pol/aktualnosci/78993,dok.html (8.06.2016). 
inaczej - składają potencjalnym dawcom pewną ofertę. Mówią: „Ja nie chcę twojej nerki za 4 tys., tylko pojedziesz sobie na wczasy do Ameryki Południowej. Poleżysz, wypoczniesz, najesz się. Dostaniesz 2 tys. dolarów w zamian przewieziesz tylko małą paczuszkę albo nałykasz się «winogron». Co ci grozi? Praktycznie nic"26.

Polska, niestety, jest jednym z tych krajów w Europie, gdzie dostęp do świadczeń zdrowotnych jest nadal trudny. Listy zapisów do lekarzy specjalistów są bardzo długie, czas oczekiwania na wizytę mierzy się w miesiącach, a nawet latach, znane wszystkim są problemy z limitami określonymi na dany rok. W koszu świadczeń zdrowotnych transplantacje są operacjami najbardziej kosztownymi, trzeba na nie czekać nawet kilka lat, figurując na Krajowej Liście Oczekujących na Przeszczepienie. Pojawienie się możliwości handlu organami staje się więc okazją do rozwiązania wielu problemów. Rozwiązanie to jest jednak nieetyczne, bo otwiera drogę do różnych nadużyć. Wielu handlarzy nie widzi tu jednak problemu. Tym bardziej, że wykrywalność tego zjawiska nie należy wcale do łatwych. W Polsce nie bierze się obecnie pod uwagę faktu, że czarny rynek handlu organami rozwija się bardzo dobrze, o czym świadczą przywołane powyżej dane o zatrzymaniach z policji ${ }^{27}$. Badający problem handlu w Polsce twierdzą, że pomiędzy samymi lekarzami krążą informacje o dobrze zorganizowanym podziemnym handlu organami. Nikt jednak oficjalnie o tym nie chce mówićs ${ }^{28}$.

Jak zauważyła Anna Dylus, prelegentka sympozjum w Kamieniu Śląskim, obecnie o problem komercjalizacji służby zdrowia w Polsce ociera się wiele osób. W przypadku transplantacji problem dotyczy dawcy i biorcy, ale także i ich rodzin, znajomych oraz lekarzy i innych pośredników obecnych $\mathrm{w}$ całym procesie. Sprawa ta nie jest obojętna komisjom etycznym oraz instytucjom ubezpieczeniowym, czy podlegającym pod państwo kasom chorych. W proces ten włączone są grupy polityczne i ustawodawcze, a także sama opinia publiczna ${ }^{29}$.

${ }^{26}$ L. Dawidowicz, „Nerkę szybko sprzedam”. W Polsce kwitnie handel organami, http://www. tvp.info/15117617/nerke-szybko-sprzedam-w-polsce-kwitnie-handel-organami (9.06.2016).

${ }^{27}$ Por. A. Sieradzka, Handel organami ludzkimi w Polsce. Czy istnieje?, http://prawoamedycyna.pl/handel-organami-ludzkimi-w-polsce-czy-istnieje/ (10.06.2016).

${ }_{28}$ Por. M. Powęska, Nerka za 30 tys. zł, płuca za milion...

${ }_{29}$ Por. A. Dylus, Problem komercjalizacji organów ludzkich, w: Etyczne aspekty transplantacji narządów, red. A. Marcol, Materiały $z$ sympozjum $w$ Kamieniu Ślaskim $w$ dniach 1516.04.1996, Opole 1996, s. 199. 


\section{Ocena moralna czynu, sposoby rozwiązywania problemu}

Sprzedaż organów, handel oraz działanie różnych gangów jednoznacznie uznaje się za nieetyczne. Nie wolno pobierać jakiejkolwiek opłaty za tkanki lub narządy od osób żywych, jak i zmarłych. Organy można jedynie ofiarować drugiej osobie - należy czynić to na zasadzie logiki daru. Handel narządami nie ma nic wspólnego $\mathrm{z}$ darem, stanowi pogwałcenie godności osoby ludzkiej oraz jest próbą urynkowienia życia ${ }^{30}$. Kodeks etyki lekarskiej uznaje za niedopuszczalne sytuacje, w których lekarz za transplantacje narządów otrzymywałby wynagrodzenie finansowe. Czytamy w nim: „Lekarz nie może otrzymywać korzyści majątkowej lub osobistej za pobierane lub przeszczepiane komórki, tkanki i narządy" ${ }^{31}$. Karta pracowników służby zdrowia wyraźnie akcentuje, że przekazanie narządów może nastąpić tylko i wyłącznie na drodze donacji na rzecz drugiej osoby. „Osoba, żywa lub zmarła, z której dokonuje się pobrania narządów, powinna być uznana za dawcę, to znaczy za kogoś, kto zgadza się, dobrowolnie na pobranie. Przeszczep zakłada uprzednią, wolną i świadomą, decyzję ze strony dawcy lub kogoś, kto reprezentuje go w sposób uprawniony, zazwyczaj członków najbliższej rodziny. «Jest to decyzja ofiarowania, bez żadnego wynagrodzenia, części ciała komuś ze względu na zdrowie i dobro innej osoby. W tym sensie akt medyczny przeszczepu umożliwia akt ofiarowania ze strony dawcy, ów szczery dar z siebie, który wyraża nasze istotne powołanie do miłości i komunii»" 32 .

W encyklice Evangelium vitae Jan Paweł II popiera transplantację, przy czym przypomina o wymogach etycznych, którymi należy kierować się podczas donacji organów. Przeszczepy są szansą dla ludzi, którzy utracili nadzieję na normalne życie i funkcjonowanie w społeczeństwie. Istotne jest jednak, aby pomoc ta nie budziła żadnych dylematów moralnych ${ }^{33}$. Biskup Rzymu mówiąc o transplantacji, jako ideał stawia przed oczyma współczesnych ludzi ofiarę, jaką z samego siebie złożył Jezus Chrystus. Ofiara

${ }^{30}$ Por. M. Machinek, Śmierć w dyspozycji człowieka. Wybrane problemy etyczne u kresu ludzkiego życia, Olsztyn 2004, s. 39.

${ }^{31}$ Kodeks etyki lekarskiej z dnia 2 stycznia 2004 r., art. 35, http://www.diametros.iphils. uj.edu.pl/serwis $/$ ? $1=1 \& p=c n f 4 \& m=44 \& j h=1 \& i h=66(10.06 .2016)$.

${ }^{32}$ Papieska Rada ds. Duszpasterstwa Służby Zdrowia, Karta pracowników służby zdrowia, Watykan 1995, nr 90.

33 Zob. Jan Paweł II, Encyklika Evangelium vitae, Watykan 1995, nr 86. 
na krzyżu przez analogię może być porównana $\mathrm{z}$ transplantacją i ofiarą złożoną z siebie dla dobra innego człowieka. „Ofiarowanie jakiejś części swojego ciała, złożenie ofiary, która stanie się skuteczna dopiero po śmierci, jest właśnie w wielu przypadkach aktem wielkiej miłości, tej miłości, która daje Życie dla innych. A więc postęp nauk medycznych umożliwił wielu osobom wyniesienie ponad śmierć ich powołania do miłości. Analogicznie do Tajemnicy Paschalnej Chrystusa, śmierć zostaje w pewien sposób zwyciężona a życie przywrócone. Śmierć i Zmartwychwstanie Pana przedstawiają najwyższy akt miłości, który nadaje głęboką wartość ofiarowaniu swojego narządu przez dawcę dla ratowania innej osoby" ${ }^{34}$.

Kościół akceptuje transplantologię, ale nie jest to akceptacja bezwarunkowa. Katechizm Kościoła Katolickiego mówi: „Przeszczep narządów jest moralnie nie do przyjęcia, jeśli dawca lub osoby uprawnione nie udzieliły na niego wyraźnej zgody. Jest on natomiast zgodny z prawem moralnym i może zasługiwać na uznanie, jeśli zagrożenia i ryzyko fizyczne i psychiczne ponoszone przez dawcę są proporcjonalne do pożądanego dobra u biorcy. Jest rzeczą moralnie niedopuszczalną bezpośrednie powodowanie trwałego kalectwa lub śmierci jednej istoty ludzkiej, nawet gdyby to miało przedłużyć życie innych osób" 35 .

Mając tak jednoznaczną negatywną opinię na temat nieetycznych aspektów transplantacji, w tym handlu ludzkimi organami, można postawić pytanie: Jak z tym problemem walczyć oraz czy możliwe jest powstrzymanie dalszego rozwoju czarnego ryku handlu organami? Odpowiedzi na te pytania nie są łatwe. Po pierwsze, do pewnych postaw muszą dorosnąć całe społeczności. Człowiekowi żyjącemu we współczesnym liberalnym i pełnym komercji świecie wydaje się, że wszystko ma swoją cenę i każdy towar można kupić. Jesteśmy wychowywani właśnie w takim utylitarystycznym duchu. Skutkuje to nieliczeniem się z pojęciami znanymi nam w teologii moralnej pod hasłem dóbr najwyższych. Jednym z nich jest życie ludzkie, któremu należy się szacunek, a za które nie można ustalić ceny. Godność, jaką posiada człowiek, ze względu na to, kim jest, musi gwarantować poszanowanie tego życia ${ }^{36}$.

${ }^{34}$ Jan Paweł II, Podarować cząstkę siebie. Fragmenty przemówienia wygłoszonego do uczestników Kongresu Transplantologicznego, Watykan 20 czerwca 1996 roku, „W Drodze” 1997 nr 1, s. 67 .

${ }^{35}$ Katechizm Kościoła Katolickiego, Poznań 2002, nr 2296.

${ }^{36}$ Por. T. Ślipko, Zarys etyki ogólnej, s. 227. 
Po drugie, o problemie nielegalnego handlu organami należy jak najwięcej mówić. Przemilczany, słabo nagłaśniany przez media temat jest okazją do rozszerzania się tego zjawiska w podziemiach. Można nawet pójść dalej i zauważyć, że brak silnej reakcji organizacji światowych i państwowych może być odczytywany jako akceptacja działań grup przestępczych. Zapotrzebowanie na narządy jest tak wielkie, że nie mówiąc o problemie handlu, przywalamy na jego szerzenie się kosztem najuboższych. Zadaniem organizacji humanitarnych winna być bezgraniczna troska o życie każdego człowieka oraz nieuciekanie od istniejących problemów, lecz ich nagłaśnianie i rozwiązywanie.

Organizacje państwowe powinny przeznaczać coraz większe środki na rozwój badań zmierzających ku leczeniu pacjentów z wadami serca, chorobami nerek czy płuc. Nowe osiągnięcia w medycynie dają nadzieję na wyzdrowienie pacjentom, którzy utracili pożądane zdrowie. Skupienie się tylko na pozyskiwaniu narządów od ludzi po śmierci lub po orzeczeniu obumarcia mózgu nie rozwiązuje nadal problemu braku narządów, a tym samym problemu handlu organami.

W końcu niezmiernie ważne jest jednakowe prawo w tak istotnej sprawie, jak handel organami ludzkimi. Organizacje międzynarodowe i prawodawstwa państwowe nie mogą w tej kwestii mówić dwugłosem. Podczas gdy jedne państwa piętnują komercjalizację organów, inne na nie przyzwalają. Ten rozdźwięk jest okazją do nielegalnych wymian i układów pomiędzy handlarzami w różnych państwach. Społeczeństwa muszą dorastać do odpowiedzialności za siebie wzajemnie, a prawodawcy - poprzez jednolite ustawy w tak ważnych sprawach - maksymalnie ograniczać możliwości działania gangów handlarzy ${ }^{37}$.

\section{Zakończenie}

Problem etyczny, jakim jest handel narządami ludzkimi, dotyczy dzisiaj wielu krajów świata. Rozwój transplantologii z jednej strony stał się nadzieją na normalne życie dla ludzi chorych, a z drugiej otworzył drogę do nielegalnego pozyskiwania organów. Problem, jakim jest handel organami, nie powinien być nigdy tematem przemilczanym. Akcje policyjne ścigające nielegalnych handlarzy organami nie mogą być pojedynczymi,

37 Por. W. Zięba, Handel organami ludzkimi, „My a Trzeci Świat” 76 (2004) nr 3, s. 5. 
spektakularnymi działaniami. Jako mało wystarczalne i niepoprawne należy uznać takie działania światowych organizacji i prawodawców, które prowadzą tylko do wydawania dokumentów świadczących o nieetycznym postępowaniu światowych gangów handlarzy, lecz nie skutkują przeciwdziałaniem przestępczości. Dodatkowym problemem są prawodawstwa nielicznych państw, w których dopuszcza się do pobierania rekompensaty finansowej za oddany narząd.

Nauka Kościoła potępia takie działania i prawodawstwa, gdyż godzą one w indywidualną godność człowieka. Na problem ten zwracał w swoim nauczaniu uwagę Jan Paweł II, a wydane przez niego dokumenty miały zawsze na celu ochronę zwłaszcza najuboższych, których świat skazuje na wyzysk w postaci pobierania od nich narządów do handlu.

Od strony moralnej nie można nigdy godzić się na handel organami ludzkimi, a zwłaszcza na przestępstwa dokonywane w celu pozyskania narządów. Istniejący problem należy odpowiednio nagłaśniać tak, aby był on coraz bardziej słyszalny, a przez to bardziej napiętnowany przez odpowiednie służby. Milczenie w twej kwestii przyczynia się do rozwoju czarnego rynku i śmierci niewinnych ludzi.

\section{Bibliografia}

Buczyński S., Snopek P., Aspekty kryminologiczne nielegalnego obrotu narządami, tkankami oraz komórkami ludzkimi, „Hygeia Public Health” 49 (2014) nr 2, S. 229-234.

Dawidowicz L., „Nerkę szybko sprzedam”. W Polsce kwitnie handel organami, http:// www.tvp.info/15117617/nerke-szybko-sprzedam-w-polsce-kwitnie-handel-organami (9.06.2016).

Dylus A., Problem komercjalizacji organów ludzkich, w: Etyczne aspekty transplantacji narządów, Materiały z sympozjum w Kamieniu Śląskim w dniach 15-16.04.1996, red. A. Marcol, Opole 1996, s. 199-212.

Gardocka M., Problem zgody domniemanej w polskiej transplantologii, „Warszawskie Studia Teologiczne" 26 (2013) nr 1, s. 247-26o.

Hoffenberg R., Christiaan Barnard: His First Transplants and Their Impact on Concepts of Death, „British Medical Journal” 12 (2001), s. 12-22.

Hołub G., O dwóch sposobach pozyskiwania organów do transplantacji, „Studia Gdańskie" 25 (2009), s. 129-146. 
Jan Paweł II, Encyklika Evangelium vitae, Watykan 1995.

Jan Paweł II, „Podarować cząstkę siebie”. Fragmenty przemówienia wygłoszonego do uczestników Kongresu Transplantologicznego, Watykan 20 czerwca 1996 roku, „W Drodze” 1997 nr 1, s. 66-68.

Jaśińska A., Łódzkie: porwania dla narządów. To nie legenda, „Dziennik Łódzki” Z 11 czerwca 2011, http://www.dzienniklodzki.pl/artykul/414909,lodzkie-porwania-dla-narzadow-to-nie-legenda,id,t.html (9.06.2016).

Kant I., Uzasadnienie metafizyki moralności, tłum. R. Ingarden, Warszawa 1984.

Katechizm Kościoła Katolickiego, Poznań 2002.

Kodeks etyki lekarskiej z dnia 2 stycznia $2004 \mathrm{r}$.

Lanzetta M., Petruzzo P., Vitale G. i in., Human Hand Transplantation: What Have we Learned?, „Transplantation Proceedings” 36 (2004), s. 664-668.

Machinek M., Śmierć $w$ dyspozycji człowieka. Wybrane problemy etyczne u kresu ludzkiego życia, Olsztyn 2004.

Meyer S., Trafficking in Human Organs in Europe. A Myth or an Actual Threat?, „European Journal of Crime, Criminal Law and Criminal Justice” 14 (2006) no. 1, s. 208-229.

Panjabi R., The Sum of A Human's Parts: Global Organ Trafficking in the Twenty-First Century, „Pace Environmental Law Review” 28 (2010) no. 1, s. 111-145.

Papieska Rada ds. Duszpasterstwa Służby Zdrowia, Karta pracowników służby zdrowia, Watykan 1995.

„Poltransplant. Biuletyn Informacyjny” $2014 \mathrm{nr} 1$ (22).

Powęska M., Nerka za 3 o tys. zł, płuca za milion. Jak wygląda handel ludzkimi organami?, http://nt.interia.pl/raporty/raport-medycyna-przyszlosci/medycyna/news-nerka-za-3o-tys-zl-pluca-za-milion-jak-wyglada-handel-ludzki,nId,1060289 (10.06.2016).

Rothman S. M., Rothman D. J., The Hidden Cost of Organ Sale, „American Journal of Transplantation" 6 (2006) no. 7, s. 1524-1528.

Scheper-Hughes N., Rotten Trade: Millennial Capitalism, Human Values and Global Justice in Organ Trafficking, ,Journal of Human Rights” 2 (2003) no. 2, s. 197-226.

Sieradzka A., Handel organami ludzkimi w Polsce. Czy istnieje?, http://prawoamedycyna.pl/handel-organami-ludzkimi-w-polsce-czy-istnieje/ (10.06.2016).

Skalski J., Historia przeszczepiania narządów, „CX-News” 28 (2009) nr 2, http:// www.cxnews.pl/historia-przeszczepiania-narzadow,201.html (6.07.2017).

Sobiak J., Przeszczepianie narządów i komórek krwiotwórczych - rys historyczny, „Nowiny Lekarskie” 80 (2011) nr 2, s. 157-161.

Ślipko T., Zarys etyki ogólnej, Kraków 2004. 
Zięba W., Handel organami ludzkimi, „My a Trzeci Świat” 76 (2004) nr 3, http:// www.maitri.pl/gazetka/my_76/html/organy.htm (6.07.2017).

\section{Streszczenie}

Wraz z rozwojem transplantologii pojawił się problem pozyskania odpowiedniej liczby organów dla osób potrzebujących przeszczepu. Zapotrzebowanie na narządy nadal znacznie przerasta liczbę dawców. W tej sytuacji narodził się nowy problem natury etycznej. Chodzi o handel ludzkimi organami. Światowa Organizacja Zdrowia (wHO) i różne autorytety moralne potępiły ten precedens. Niestety, są dziś kraje na świecie, jak choćby Indie czy Mołdawia, które dopuszczają możliwość majątkowej rekompensaty za oddanie narządów. Wśród wielu przyczyn tego przyzwolenia należy wskazać skrajną biedę ludzi, którzy w handlu własnymi organami widzą nadzieję na poprawę bytu.

Celem artykułu jest zaprezentowanie problemu handlu organami jako ogólnoświatowego problemu, na przykładzie poszczególnych krajów świata, w tym Polski. Autor wyjaśnia, w czym tkwi zło moralne takich czynów, wskazuje możliwe sposoby rozwiązania tego problemu.

\section{Słowa kluczowe}

narządy, handel organami, transplantologia, donacja organów

\section{Summary}

\section{Trafficking in Human Organs}

With the development of transplantation this occur very important problem obtaining the right amount of organs for people who need a transplant. The demand for organs is still far surpasses the number of donors. In the context of this situation was born a new problem ethical. As for the trade in human organs. The World Health Organization (wHO), various moral authorities, condemned this precedent. Unfortunately, there are still countries in the world, such as India and Moldova, which are open to pecuniary compensation for the donation. Among the many reasons for this consent should indicate the extreme poverty of the people who trade in their own bodies they see hope for a better life. 
The aim of the article is to present the problem of organ trafficking as a global problem, for example the various countries of the world, including Polish. The author points out what's the moral evil of such acts, shows a possible way to solve this problem.

\section{Keywords}

organs, organ trafficking, transplantation, organ donation 